\title{
Robust in vitro propagation and regeneration of ubi kuning high beta carotene cassava genotype through somatic embryogenesis
}

\author{
SUPATMI ${ }^{1, \vartheta}$, HANI FITRIANI ${ }^{1, v,}$, NURHAMIDARR RAHMAN ${ }^{1}$, N. SRI HARTATI ${ }^{1}$, ENNY SUDARMONOWATI $^{1}$ \\ Research Centre for Biotechnology, Indonesian Institutes of Sciences. Cibinong Science Centre, Jl. Raya Bogor KM 46, Cibinong 16911, West Java, \\ Indonesia. Tel.: +62 218754587, Fax: +62 218754588, ”email: patmi_bio@yahoo.com, ${ }^{\text {v } h f i t r i a n i 76 @ y a h o o . c o m ~}$
}

Manuscript received: 21 August 2017. Revision accepted: 27 October 2017.

\begin{abstract}
Supatmi, Fitriani H, Rahman N, Hartati NS, Sudarmonowati E. 2017. Robust in vitro propagation and regeneration of ubi kuning high beta carotene cassava genotype through somatic embryogenesis. Nusantara Bioscience 9: 352-360. Ubi kuning is a local genotype of cassava with high beta carotene content but the development of this genotype is still low because of plant disease susceptibility. Objectives of this study were to robust induce and regenerate somatic embryos of ubi kuning in vitro as well as to define a protocol of cyclic somatic embryogenesis of ubi kuning. Different size of leaf lobes, various concentration of picloram and different light conditions were tested to produce an effective and efficient somatic embryos (SEs).The best response of the induction of embryogenic callus was observed in leaf lobes explant with range size of $1-3 \mathrm{~mm}$ and $>5 \mathrm{~mm}$ cultured on induction medium (MS $+4 \%$ sucrose $+4 \mu \mathrm{M} \mathrm{CuSO} 4+0.1 \mathrm{mM}$ Glutamine $+0.8 \%$ Microagar) supplemented with either 10 or $18 \mathrm{mg} / \mathrm{L}$ picloram grown under dark light for 4 weeks. Retransferring embryogenic callus to the same medium supplemented with $16 \mathrm{mg} / \mathrm{L}$ picloram gave the advanced development of primary somatic embryos (PSEs) after $70 \mathrm{~d}$ grown under both dark and light condition treatments. A positive correlation between globular and cotyledon stages was obtained in all treatments $(\mathrm{P} \leq 0.01)$. The highest shoot and root growth $(30 \%$ and $25 \%)$ was achieved in the regeneration of cotyledonary like-tissues cultured on callus embryogenic media (CEM) (MS basal $+2.5 \mu \mathrm{M} \mathrm{CuSO} 4+$ $3 \%$ sucrose $+2.75 \mathrm{~g} / \mathrm{L}$ phytagel) supplemented with $1.6 \mathrm{mg} / \mathrm{L}$ of BAP (6-Benzylaminopurine).
\end{abstract}

Keywords: Light conditions, picloram, somatic embryogenesis, ubi kuning

\section{INTRODUCTION}

Cassava (Manihott esculenta Crantz.), known as one of important crop in the lowland tropics, is a major source of calories to nearly 500 million people worldwide (Montagnac et al. 2009). Cassava is also the targeted crops in the biofortification programme for increasing its nutritional value because it becomes a staple food in most of Sub-saharan Africa (Thakkar et al. 2009). In Indonesia, the total production of cassava roots reach more than 5 million tons per year (Hermiati et al. 2012). However, most of used-cassava varieties still have poor nutritional quality such as low contents of provitamin A (proVA) carotenoids, iron, zinc and protein and also toxic cianogens (Njoku et al. 2011; Mburu et al. 2012). According to Ssemakula et al. (2007) the yellow flesh (YF) colour found in some cassava genotypes is associated with the density of micronutrients, especially carotenes. Carotenes ( $\alpha$-Carotene, $\beta$-carotene, lycopene) representing the most multifacet group of pigments in nature, with colours varying from yellow to red, is found in photosynthetic and non-photosynthetic tissues such as roots, seeds and fruits (Ferreira 2008). Betacarotene is the most potent and widespread form of provitamin A (Maroya et al. 2012). Ubi kuning is one of local genotypes of cassava, which potentially contains a high beta carotene with a range of 0.018-0.026 ppm (Hartati et al. 2012). It has also been reported that ubi kuning has the ability to survive under drought stress conditions (Hartati et al. 2013). However, the development of this genotype is still poor because of its high susceptibility to plant diseases.
In vitro clonal propagation is the potential method for fast multiplication of plant genotypes in order to maximize the plant genetic exploitation for breeding purposes (Kumar et al. 2008). In vitro clonal propagation through somatic embryogenesis is rapid methods of mass in vitro propagation which could be considered as the main way to many technologies and purposes. According to Von Arnold et al. (2002) somatic embryogenesis is the development process of plant bipolar embryos, known as somatic embryos, which it is derived from a nonzygotic cell without vascular connections with the original tissue. Besides somatic embryogenesis is used for clonal mass propagation, it is also a valuable tool for genetic improvement of many plant species because of its single cell origins (Stasolla and Yeung 2003). Somatic embryos play a key role in genetic transformation methods, cell selection, somatic hybrid and polyploid plant production (Aboshama 2011; Kamle et al. 2011). Two critical events are involved in the early programme of somatic embryogenesis process i.e., (i) the induction of cytodifferentiation of pre-embryonic cells, and, (ii) the unfolding development of these pro-embryonic cells forms the advanced embryonic stages (primary somatic embryos) (Kumar et al. 2008). In vitro plant propagation of cassava through somatic embryogenesis has been succesfully reported (Ihemere 2003; Hankoua et al. 2005; Saelim et al. 2005; Atehnkeng et al. 2006; and Feitosa et al. 2007), although the succesful induction of those somatic embryos is depended on many factors including genotypes, explant source, the concentration and combination type of plant 
growth regulators as well as the environmental conditions (Saelim et al. 2006; Sudarmonowati et al. 2009). Ihemere (2003) has reported that cassava cultivars originated from Africa gave a different response in culture media during the process of somatic embryos induction compared with South American varieties.

Therefore, objectives of this study were to induce and regenerate somatic embryos of ubi kuning in vitro as well as to define a protocol of cyclic somatic embryogenesis by employing different size of leaf lobes as explant source, various concentrations of picloram in culture media and different treatments of light conditions.

\section{MATERIALS AND METHODS}

\section{Plant materials}

The axenic culture of ubi kuning cassava was prepared by harvesting shoot stems from Field Station of Research Center for Biotechnology, Indonesian Institute of Sciences which were then surface sterilized using Sunlight (commercial detergent) under tap water running for $45 \mathrm{~min}$. Afterward, they were sterilized by $4 \%$ Dethane (antifungiside) for $60 \mathrm{~min}$ followed by v/v Haiter ( $5 \%$ sodium hypochlorite solution) for $5 \mathrm{~min}$ and $70 \%$ ethanol for 1 min. After washing three times with steriled-reverse osmosis water, shoot apex and axillary buds were excised and cultured on Murashige and Skoog (MS medium) (Murashige and Skoog 1962) Supplemented with 4\% sucrose and solidified with $0.7 \%$ Swallow agar. The $\mathrm{pH}$ was adjusted to 5.8 prior to autoclaving. The prolifereted shoots were repeatedly transferred in the same medium at 30 days intervals. These culture were grown under white fluorescent light for $16 \mathrm{~h}$ /day photoperiod and $25 \pm 2{ }^{\circ} \mathrm{C}$ until they produced young leaf lobes.

\section{Embryogenic callus induction}

Young leaf lobes (immature leaf lobes from shoot tips) taken from shoots and axillary bud in vitro were isolated and used for induction of somatic embryos. They were excised by using scalpel and then cultured on induction medium (MS $+4 \%$ sucrose $+4 \mu \mathrm{M} \mathrm{CuSO} 4+0.1 \mathrm{mM}$ Glutamine $+0.8 \%$ Microagar) at $25-28^{\circ} \mathrm{C}$. Different size type of leaf lobes (1-3 $\mathrm{mm}$ and $>5 \mathrm{~mm}$-long) and various concentrations of phytohormone picloram (10, 16, 18 $\mathrm{mg} / \mathrm{L})$ were tested for their efficiency in somatic embryo induction medium and cultured in dark condition at the same condition for 3-4 weeks. Embryogenic callus formation was observed using stereo microscope with $8 \mathrm{x}$ magnification LEICA E24HD. The frequency of embryogenic callus formation [ (explants with embryogenic callus/ total of explants)*100] was then evaluated after 3 weeks of culture.

\section{Induction of cyclic somatic embryogenesis}

After 4 weeks of culture on callus induction medium, embryogenic callus segments were then cut into small clump pieces and transferred to induction medium with various concentration of picloram $(10,16,18 \mathrm{mg} / \mathrm{L})$. They were then placed into a different light conditions (dark and light conditions) to produce cyclic somatic embryogenesis with the first cycle was known as primary somatic embryos (PSE). Each treatment consisted of three replication with each replication comprised of 10 explants. Proembrionic stage developed from embryogenic callus segments was recorded after 70 days of culture on treatment medium and light conditions. Macroscopic features of pre-embryonic stages i.e globular and cotyledonary-like tissues shape of somatic embryos were observed using a stereo microscope LEICA E24HD with 8x magnification.

\section{Regeneration of somatic embryo}

The mature primary somatic embryos (PSEs) which could be seen from the formation of cotyledonary liketissue was then cultured in CEM (callus embryogenic media) comprised of $\mathrm{MS}$ basal $+2.5 \mu \mathrm{M} \mathrm{CuSO} 4+3 \%$ sucrose $+2.75 \mathrm{~g} / \mathrm{L}$ phytagel supplemented with various concentrations of $\operatorname{BAP}(0 ; 0.8 ; 1.2 ; 1.6 \mathrm{mg} / \mathrm{L})$. Each treatment consisted of 4 replication plate with each plate comprised of 5 explants. The observation was conducted after three weeks of culture including the number of survival rate, shoot and root formation, and the cotyledonary like tissues using a stereo microscope LEICA E24HD with 8x magnification.

\section{Statistical analysis}

Number of globular, cotyledonary stages, shoot and root growth resulted from treatment media were analysed by a mixed-model ANOVA and means by the Duncan test. Data resulted from a different light conditions (dark and light condition) treatment was also analyzed by analysis of variance $\mathrm{T}$ test. Correlation coefficients were analysed by Bivariate test continued with Pearson test. All of results were analysed using SPSS software (SPSS for windows 16.0 version).

\section{RESULTS AND DISCUSSIONS}

\section{Induction of embryogenic callus}

In order to induce callus formation, preliminary experiment using various explants (i.e nodes, leaves and immature leaf lobes) of ubi kuning cassava cultured on MS supplemented with various plant growth regulators such as NAA (1-Naphthaleneacetic acid) and Kinetin has been conducted (data not shown). Among these explants, callus was only obtained using leaf lobes despite these callus did not initially form embryogenic callus. Afterward, leaf lobes were primary used as explant material in the induction of embryogenic callus by employing different size type of leaf lobes and various concentration of picloram. Different size type of leaf lobes (1-3 $\mathrm{mm}$ and $>5 \mathrm{~mm}$-long) have been tested for their efficiencies in the production of embryogenic callus by culturing on to (MS $+4 \%$ sucrose + $4 \mu \mathrm{M} \mathrm{CuSO} 4+0.1 \mathrm{mM}$ Glutamine $+0.8 \%$ Microagar) supplemented with various concentrations of picloram (10, $16,18 \mathrm{mg} / \mathrm{L})$ in dark light conditions at $25-28^{\circ} \mathrm{C}$. Most of explants treated with various concentration of picloram could develop into callus formation after they were incubated for 3 weeks in dark light condition. The highest 
callus formation (85 and 100\%) was obtained after leaf lobes were cultured on to induction medium supplemented with $16 \mathrm{mg} / \mathrm{L}$ picloram (PG16) (Table 1). Meanwhile, the lowest frequency of callus formation (63 and 44\%) was achieved in those explants cultured on to induction medium supplemented with $10 \mathrm{mg} / \mathrm{L}$ picloram (PG10) (Table 1).

Of all size type of leaf lobes which were treated, both size of 1-3 and $>5 \mathrm{~mm}$ showed a high response of callus formation. However, among the developed-callus formation, not all of them were embryogenic. The obtained embryogenic calluses were characterized by their yellowish colour and friability (Figure 1). Results showed that no embryogenic callus was obtained when explants of size $>5 \mathrm{~mm}$ were cultured on induction medium supplemented with $16 \mathrm{mg} / \mathrm{L}$ picloram (PG16) (Table 1). On the other hand, leaf lobes with size of $>5 \mathrm{~mm}$ cultured on medium induction supplemented with $10 \mathrm{mg} / \mathrm{L}$ picloram (PG10) or $18 \mathrm{mg} / \mathrm{L}$ picloram (PG18) resulted in 100\% embryogenic callus response (Figure $1 \mathrm{~b} \& 1 \mathrm{e})$. The best response of embryogenic callus formation was also obtained from leaf lobes with range size of 1-3 mm cultured on both PG10 and PG18 media with the percentage of 60 and 64, respectively (Table 1, Figures $1 \mathrm{a} \& 1 \mathrm{~d}$ ). This is in accordance with Saelim et al. (2006) who reported that leaf lobes is the best material for the induction of somatic embryos in cassava Asian cultivars and with Ravindran et al. (2015) in African and Indian cassava cultivars. Furthermore, leaf lobes had a high response in the production of somatic embryos in most of culture media supplemented with various plant growth regulators although the response of somatic embryo development is depended on physiological state of plants for providing leaf lobes (Atehnkeng et al. 2006, Sudarmonowati et al. 2009).

Somatic embryos was initially formed by the development of glowsy embryogenic callus after three weeks cultured on induction medium supplemented with picloram under dark light condition at $25-28^{\circ} \mathrm{C}$ (Figure 1). Moreover, observations using stereo microscope showed that the early pro-embryonic stage, known as noduler shape of somatic embryos, was formed on the callus surface (Figure 1). Of all well-developed somatic embryos, the fastest and the largest number of noduler shape was apparently obtained in PG10 and PG18 media (Figure 1a1e). According to Zavattieri et al. (2010), auxin (i.e picloram) is considered to be the most important plant growth regulators in the regulation of somatic embryogenesis. Both the endogenous auxins and the application of exogenous auxins determines the success process of somatic embryo induction and further PSEs stage development to become plantlets (Jimenez. 2001).
These results were similar to other published papers, which employed media supplemented with various concentrations of picloram in the induction of somatic embryos in many cassava genotypes such as KU 50 and Hanatee (Saelim et al. 2006), cassava genotypes from Northeast Brazil (Feitosa et al. 2007), Indonesian local genotype (i.e Iding, Gebang, Apuy, Roti) (Sudarmonowati et al. 2009 and Fitriani et al. 2012), although the source of explants, the composition of culture media, and the concentration of plant growth regulators were generally different.

\section{Maturation and Germination of Primary Somatic Embryos (PSEs)}

The maturation process of somatic embryogenesis is an important stage because the degree of maturation can significantly affect the germination capability of somatic embryos (SEs) (Malabadi \& Van Staden 2005; Hankoua et al. 2006). During the maturation stage, the somatic embryos will accumulate reserves and achieve desiccation tolerance (Hankoua et al. 2006). This study showed that somatic embryos stop developing the nodular stage in induction media containing picloram grown under dark light conditions for 4 week. For this reason, those nodular stages were re-transferred onto the same media. To evaluate the development of those somatic embryos; therefore, they were grown under different light condition (dark and light condition) treatments. Interestingly, those nodular stages of somatic embryos were subsequently developed into pre-embryonic stages i.e globular stage and immature cotyledon stage both under dark and light conditions. The development of pre-embryonic stages in terms of light white and yellow globular, heart, torpedo and green immature cotyledon stages was observed from 7 to 70 days (Table 2 and Figure 2).

Table 1. The response of ubi kuning callus formation derived from a different leaf lobes size type cultured on a different picloram concentration medium after grown under dark condition for 3 weeks

\begin{tabular}{lcccc}
\hline Callus & Leaf lobes & \multicolumn{3}{c}{ Induction media } \\
development & Type size & PG10 & PG16 & PG18 \\
\hline Callus formation & $1-3 \mathrm{~mm}$ & 63 & 85 & 56 \\
$(\%)$ & $>5 \mathrm{~mm}$ & 44 & 100 & 83 \\
Embryogenic & $1-3 \mathrm{~mm}$ & 64 & 18 & 60 \\
callus formation & & & & \\
$(\%)$ & $>5 \mathrm{~mm}$ & 100 & 0 & 100 \\
\hline
\end{tabular}

Note: Induction media (MS $+4 \%$ sukrosa $+4 \mu \mathrm{M} \mathrm{CuSO} 4+0.1$ $\mathrm{mM}$ glutamine $+0.8 \%$ microagar) supplemented with $10 \mathrm{mg} / \mathrm{L}$ picloram (PG10), $16 \mathrm{mg} / \mathrm{L}$ picloram (PG16), $18 \mathrm{mg} / \mathrm{L}$ picloram (PG18)

Table 2. The differences of ubi kuning primary somatic embryos stages $70 \mathrm{~d}$ after treatment with various concentrations of picloram under dark and light conditions

\begin{tabular}{|c|c|c|c|c|}
\hline \multirow{3}{*}{ Media } & \multicolumn{2}{|c|}{ Globular stage } & \multicolumn{2}{|c|}{ Immature cotyledon stages } \\
\hline & Dark condition & Light condition & Dark condition & Light condition \\
\hline & ns & $*$ & ns & ns \\
\hline PG10 & $2.00 \pm 0.87^{\mathrm{ns}}$ & $5.00 \pm 1.74^{\mathrm{b}}$ & $1.47 \pm 0.65^{\mathrm{ns}}$ & $3.33 \pm 1.00^{\mathrm{ns}}$ \\
\hline PG16 & $3.00 \pm 1.02^{\mathrm{ns}}$ & $17.00 \pm 5.71^{\mathrm{a}}$ & $1.44 \pm 0.43^{\mathrm{ns}}$ & $3.31 \pm 1.05^{\mathrm{ns}}$ \\
\hline PG18 & $3.19 \pm 2.45^{\mathrm{ns}}$ & $3.19 \pm 1.55^{\mathrm{b}}$ & $0.19 \pm 0.14^{\mathrm{ns}}$ & $2.31 \pm 1.08^{\mathrm{ns}}$ \\
\hline
\end{tabular}

Note: Means \pm standard error within a column followed by the different letters in each column are significantly different at $\mathrm{P} \leq 0.05$ by ANOVA. ns: not significance, *: significantly different 


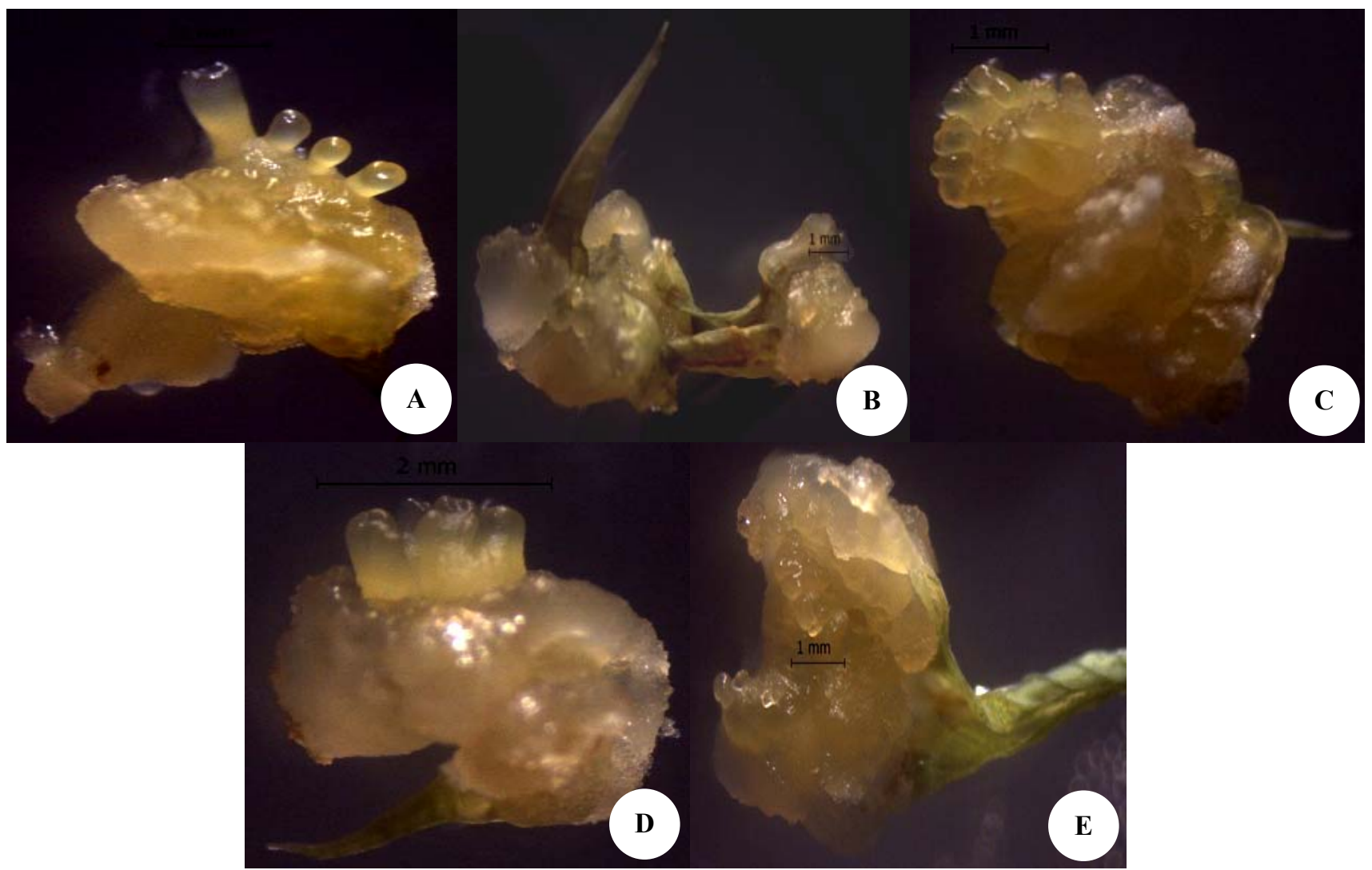

Figure 1. Formation of somatic embryo of ubi kuning at noduler stage derived from various leaf lobes size after three weeks of culture on induction medium supplemented with various picloram concentration: A. PG10 (1-3mm), B. PG10 (>5mm), C. PG16 (1-3mm), D. PG18 (1-3mm), E. PG18 (>5mm)

In this study, the observation of PSEs maturation and germination was focussed to the observation of globular and immature cotyledon stages due to the fastest cycle of other somatic embryo stages i.e heart and torpedo stage which could not be observed effectively. Those PSEs cycle was observed microscopically after 7 days cultured in both different picloram concentration and light conditions (Table 2 and Figure 2).

Generally, the differentiation of PSEs beyond the globular stage and its subsequent maturation requires the removal of growth regulators from the medium or reduction of their concentrations (Kordestani \& Karami 2008). However, in this study, retransferring to the same media supplemented with picloram concentration grown either under dark or light condition showed the advanced development of ubi kuning somatic embryos. Interestingly, $16 \mathrm{mg} / \mathrm{L}$ picloram-containing medium gave the best response for PSEs development compared to other picloram concentrations (Figure 2c). In terms of light treatment, the best response of PSEs development derived from globular stages was also obtained in media containing $16 \mathrm{mg} / \mathrm{L}$ picloram under light conditions at 70 days of culture ( $\mathrm{P} \geq 0.05)$ (Table 2). PSEs also showed to be welldevelop in dark condition; however, the development of PSEs was slower and apparently turned in brown colour than those in light condition. This result was similar to D’Onofrio \& Morini (2005) who reported that light quality affect the development of somatic embryogenesis in Cydonia oblonga leaves culture. In addition, light is known to affect somatic embryogenesis starting from the induction process and some morphological characteristics of somatic embryo development (Husaini et al. 2011).

From correlation analysis between globular and immature cotyledon stages grown under both dark and light conditions, results showed that the significant correlation between different SEs stage and light condition has been obtained (Table 3 and Figure 3$)$. A positive correlation $(\mathrm{P} \leq$ $0.05)$ was observed at globular and immature cotyledon stage grown under dark conditions $\left(\mathrm{R}^{2} \mathrm{a}=0.339\right.$, Figure. $3 a)$. Furthermore, a positive correlation $(\mathrm{P} \leq 0.01)$ was also observed at globular and immature cotyledon grown under light conditions ( $\left(\mathrm{R}^{2} \mathrm{a}=0.424\right.$, Figure. $\left.3 b\right)$. It means that the more globular formation would likely form the more immature cotyledon when they were grown both under dark and light conditions. Therefore, it is predicted that the germination to be shoots will be highly obtained. This result was in accordance to Saelim et al. (2007) who reported that the maturation of primary and secondary somatic embryos could happen when the cyclic somatic embryogenesis including the formation of globular, heart and torpedo stages can form distinct bipolar structures with expanded cotyledons (Saelim et al. 2007). Jimenev (2001) also reported that the formation of pre-embryonic mass is associated with the increase of DNA demethylation leading to the gene product synthesis; therefore, pre-embryonic mass should complete the globular stage of somatic embryogenesis prior to generating a new plant variety . 


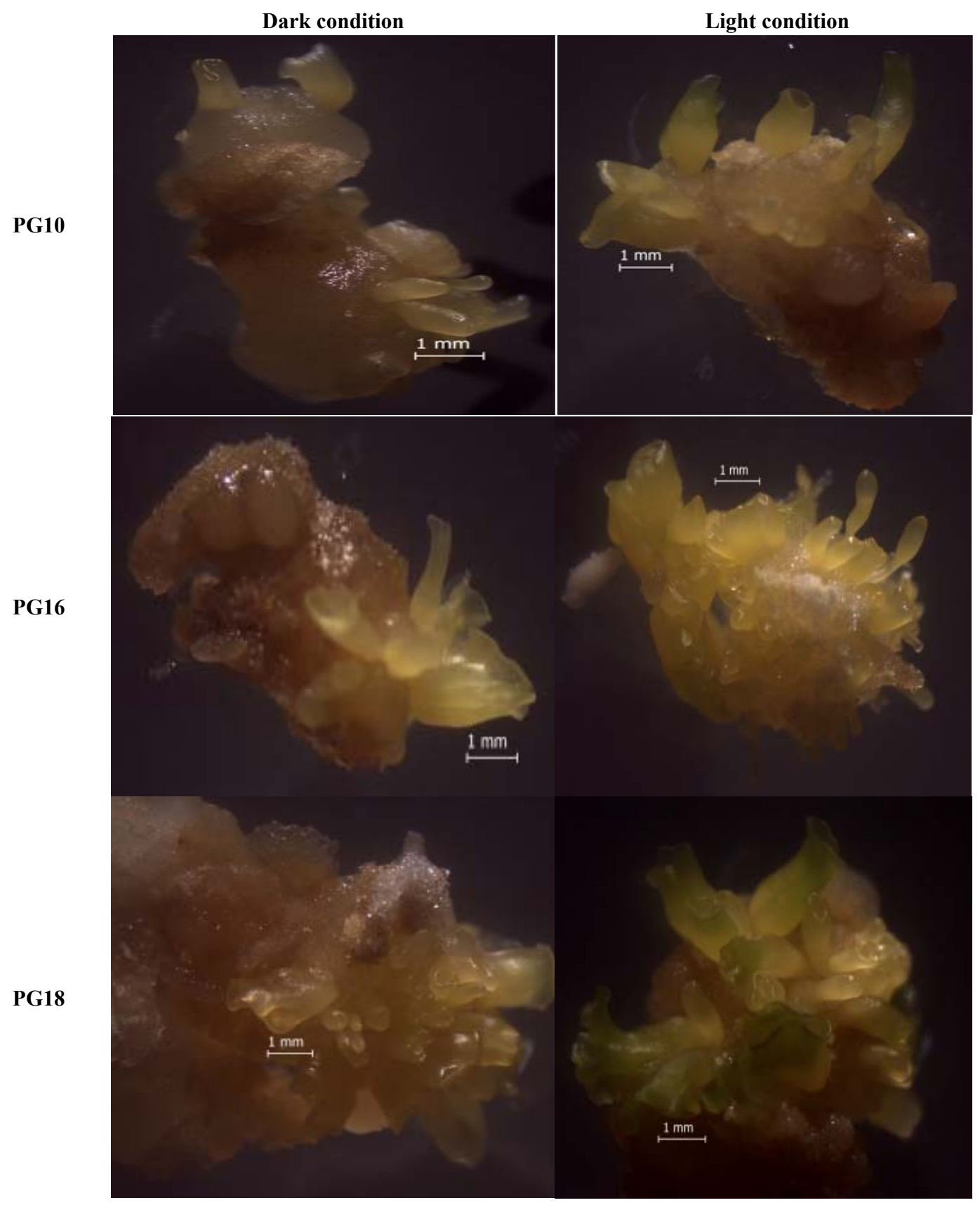

Figure 2. The differences of somatic embryos development at globular and immature cotyledon stages after 7 days of culture on induction medium supplemented with various picloram concentrations under both dark and light condition

\section{Regeneration of cotyledonary like-tissues of ubi kuning somatic embryos}

One of the important aspect for in vitro clonal propagation through somatic embryogenesis is the ability of plant to regenerate and to self-multiplicate from cell cultures and tissues to be plantlets. In the process of plant propagation in vitro, the need of plant growth regulators is very important in order to trigger the shoot growth for massive somatic embryo regeneration (Atehnkeng et al. 2006). One of the plant growth regulators often used is BAP. In this study, the varied concentration of BAP ( 0 ;
0,$8 ; 1,2 ; 1,6 \mathrm{mg} / \mathrm{L}$ ) in the CEM (Callus embryogenic media) which comprised of MS basal $+2.5 \mu \mathrm{M} \mathrm{CuSO} 4+$ $3 \%$ sucrose $+2.75 \mathrm{~g} / \mathrm{L}$ phytagel could initiate the formation of shoot and root of ubi kuning PSEs in the late-preembryonic stages namely cotyledonary like-tissues after 7 DAP ( days after planting). The emerging shoot could be seen from the elongation of shoot-up and the formation of the initial leave candidates, while the root formation could be seen from the white long spot in the basal of explants (Table 4 and Figure 4). 
SE in dark room

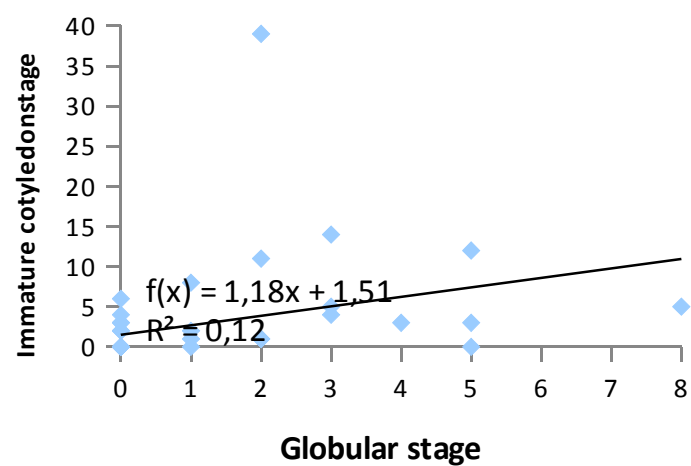

$\mathbf{A}$
SE in light room

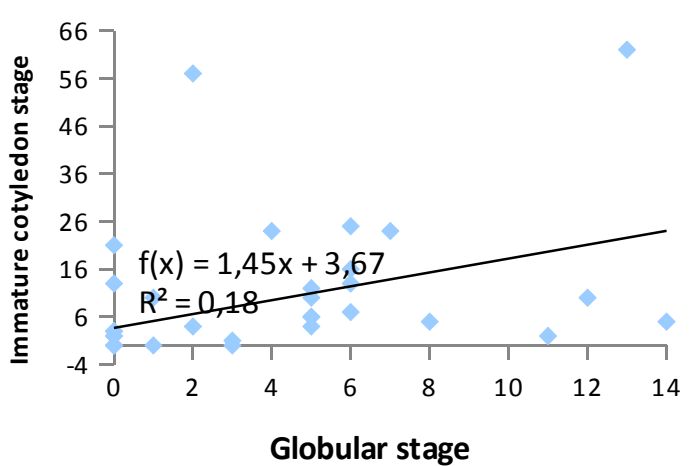

B

Figure 3. Relation of globular and immature cotyledon stage of ubi kuning somatic embryos treated at $70 \mathrm{~d}$ under dark (A) and light room conditions $(\mathrm{B})$

Table 3. Coefficients of correlations $(\mathrm{R} 2 \mathrm{a})$ of globular and cotyledonary like tissues of ubi kuning somatic embryos treated at $70 \mathrm{~d}$ under dark and light room conditions

\begin{tabular}{lllll}
\hline & Cot1 & Glob1 & Cot2 & Glob2 \\
\hline Cot1 & 1 & $0.339^{*}$ & $0.283 \mathrm{~ns}$ & $0.189 \mathrm{~ns}$ \\
Glob1 & - & 1 & -0.023 & $-0.016 \mathrm{~ns}$ \\
Cot2 & - & - & 1 & $0.424^{* *}$ \\
Glob2 & - & - & - & 1 \\
\hline
\end{tabular}

Cot $=$ Cotyledonary like tissues, Glob $=$ Globular, $1=$ in dark condition 2 = in light condition. Values followed by *, and ** represent significance differences at $\mathrm{P} \leq 0.05$ and $\mathrm{P} \leq 0.01$. Means followed by $n s$ do not represent significant differences at $\mathrm{P} \geq 0.05$

Table 4. The percentage of survival rate and regeneration of cotyledonary-like tissues of ubi kuning primary somatic embryos after three weeks of culture on the treatment media

\begin{tabular}{|c|c|c|c|c|c|}
\hline $\begin{array}{l}\text { Treatment } \\
\text { media }\end{array}$ & & $\begin{array}{c}\text { Survival } \\
\text { rate (\%) } \\
\text { (NS) }\end{array}$ & $\begin{array}{c}\text { Shoot } \\
\text { (\%) } \\
\text { (NS) }\end{array}$ & $\begin{array}{l}\text { Root } \\
\text { (\%) } \\
\text { (NS) }\end{array}$ & $\begin{array}{c}\text { Cotyled } \\
\text { onary } \\
\text { like- } \\
\text { tissue } \\
\text { (\%) } \\
\text { (NS) }\end{array}$ \\
\hline $\begin{array}{l}\mathrm{CEM}+\mathrm{BAP} \\
\mathrm{mg} / \mathrm{L}\end{array}$ & 0 & $100 \pm 0^{\mathrm{ns}}$ & $\begin{array}{c}10 \pm \\
5,77^{\text {ns }}\end{array}$ & $15 \pm 5^{\mathrm{ns}}$ & $75 \pm 5^{\text {ns }}$ \\
\hline $\begin{array}{l}\mathrm{CEM}+\mathrm{BAP} \\
\mathrm{mg} / \mathrm{L}\end{array}$ & 0,8 & $100 \pm 0^{\mathrm{ns}}$ & $\begin{array}{c}20 \pm \\
14,14^{\mathrm{ns}}\end{array}$ & $\begin{array}{c}15 \pm \\
9,57^{\mathrm{ns}}\end{array}$ & $\begin{array}{c}80 \pm \\
8,17^{\mathrm{ns}}\end{array}$ \\
\hline $\begin{array}{l}\mathrm{CEM}+\mathrm{BAP} \\
\mathrm{mg} / \mathrm{L}\end{array}$ & 1,2 & $100 \pm 0^{\mathrm{ns}}$ & $\begin{array}{c}15 \pm \\
9,57^{\text {ns }}\end{array}$ & $\begin{array}{c}20 \pm \\
14,14^{\mathrm{ns}}\end{array}$ & $\begin{array}{c}70 \pm \\
12,91^{\mathrm{ns}}\end{array}$ \\
\hline $\begin{array}{l}\mathrm{CEM}+\mathrm{BAP} \\
\mathrm{mg} / \mathrm{L}\end{array}$ & 1,6 & $100 \pm 0^{\mathrm{ns}}$ & $\begin{array}{c}30 \pm \\
12,91^{\mathrm{ns}}\end{array}$ & $\begin{array}{c}25 \pm \\
9,57^{\mathrm{ns}}\end{array}$ & $\begin{array}{c}55 \pm \\
9,57^{\mathrm{ns}}\end{array}$ \\
\hline
\end{tabular}

Note: Mean \pm standard error followed by $n s$ in the same column do not represent significant differences $P \geq 0.05$. by ANOVA. Each data consisted of 4 replication plate with each plate comprised of 5 explants. CEM (callus embryogenic media) comprised of MS basal $+2.5 \mu \mathrm{M} \mathrm{CuSO} 4+3 \%$ sucrose $+2.75 \mathrm{~g} / \mathrm{L}$ phytagel
Results from the first day after planting (1 DAP) to the third DAP showed that not all observed explants could develop the shoot or root formation. In order to know the differences amongst the treatments, a further analysis using ANOVA test followed by Duncan test $(\alpha=5 \%)$ was conducted after three weeks of observation (Table 4). Results showed that the cotyledonary like-tissues of $u b i$ kuning derived from PSEs showed a positive response after they were treated in CEM media supplemented with various concentrations of BAP. Those responses could be seen in the observed parameters including the percentage of survival rate, the shoot growth, the root growth and the development of further cotyledonary like-tissues. However, the further analysis using Duncan test showed that those observed parameters did not show a significant difference in each treatment media. This results indicated that the treatment of various concentration of BAP did not show a different response in all observed explants because three weeks is not sufficient to get optimal response. According to Saelim et al. (2006), the regeneration process or shoot growth of callus is very complex depended on many factors including genotype, type of explants, the balance concentration of plant growth regulators and the physiological conditions of callus. Based on three-weeks of observation, all the explants were in good conditions. Generally, the survival rate of explants was 100\% during the observation. This might correlate with the approprite concentration of CEM media and plant growth regulators which did not cause the tissue damage so that the explant death could be hindered effectively. Another shoot growth parameters showed that explants treated in CEM media supplemented with $1.6 \mathrm{mg} / \mathrm{L}$ of BAP had a higher percentage of shoot growth (30\%) (Table 4 and Figure 4). The increase number of shoot formation obtained in the high concentration of BAP apparently happen due to the ability of cytokinin to increase the protein synthesis (Mohd et al. 2011). According to Kurakawa et al. (2007), cytokinin is an affective plant growth regulators which is 
consistently triggered the double shoot formation in meristem culture, apex shoot culture and shoot culture. However, the need of cytokinin in each plants is different in both type and concentration, but most of plants give the positive response in the addition of synthetic cytokinin such as BAP.

Based on the root formation of the explants, result showed that the root growth of cotyledonary like-tissues derived from PSEs of ubi kuning was obtained from $15 \%$ to $25 \%$. The highest root growth was achieved in explants cultured on treatment media supplemented with $1.6 \mathrm{mg} / \mathrm{L}$ BAP.. Meanwhile, the supplementation of cytokinin (BAP) in the treatment media could not inhibit the root growth development and also trigger the shoot formation. This could be seen in most of explants cultured in all CEM media supplemented with various concentration of BAP showing the root development although the root growth across the treatment media did not significantly different based on data analysis using ANOVA followed by Duncan test (Table 4 and Figures 4 ).

Of all cyclic somatic embryogenesis and regeneration of ubi kuning, most of regenerated somatic embryos could form plantlet (Figure 5). However, the eficiency of multiplication rate and the best media for plantlet growth as well as the efficiency of plantlet survival rate in the field are still further observed.

As conclusion, somatic embryogenesis of ubi kuning is significantly depended on the size of leaf lobe explants, the concentration of picloram in the culture medium and also the light condition. The cyclic somatic embryogenesis protocol and the efficiency of somatic embryos development of ubi kuning has been established, allows for the application of ubi kuning somatic embryos for clonal propagation and other genetic engeneering purposes. The regeneration of somatic embryos to be plantlets had been established although the efficiency of plantlet survival rate in the field should be further observed.

\section{Growth}

Treatments

Induction medium + BAP $0 \mathrm{mg} / \mathrm{L}$

Induction medium + BAP $0,8 \mathrm{mg} / \mathrm{L}$

Induction medium + BAP $1,2 \mathrm{mg} / \mathrm{L}$

Induction medium + BAP $1,6 \mathrm{mg} / \mathrm{L}$
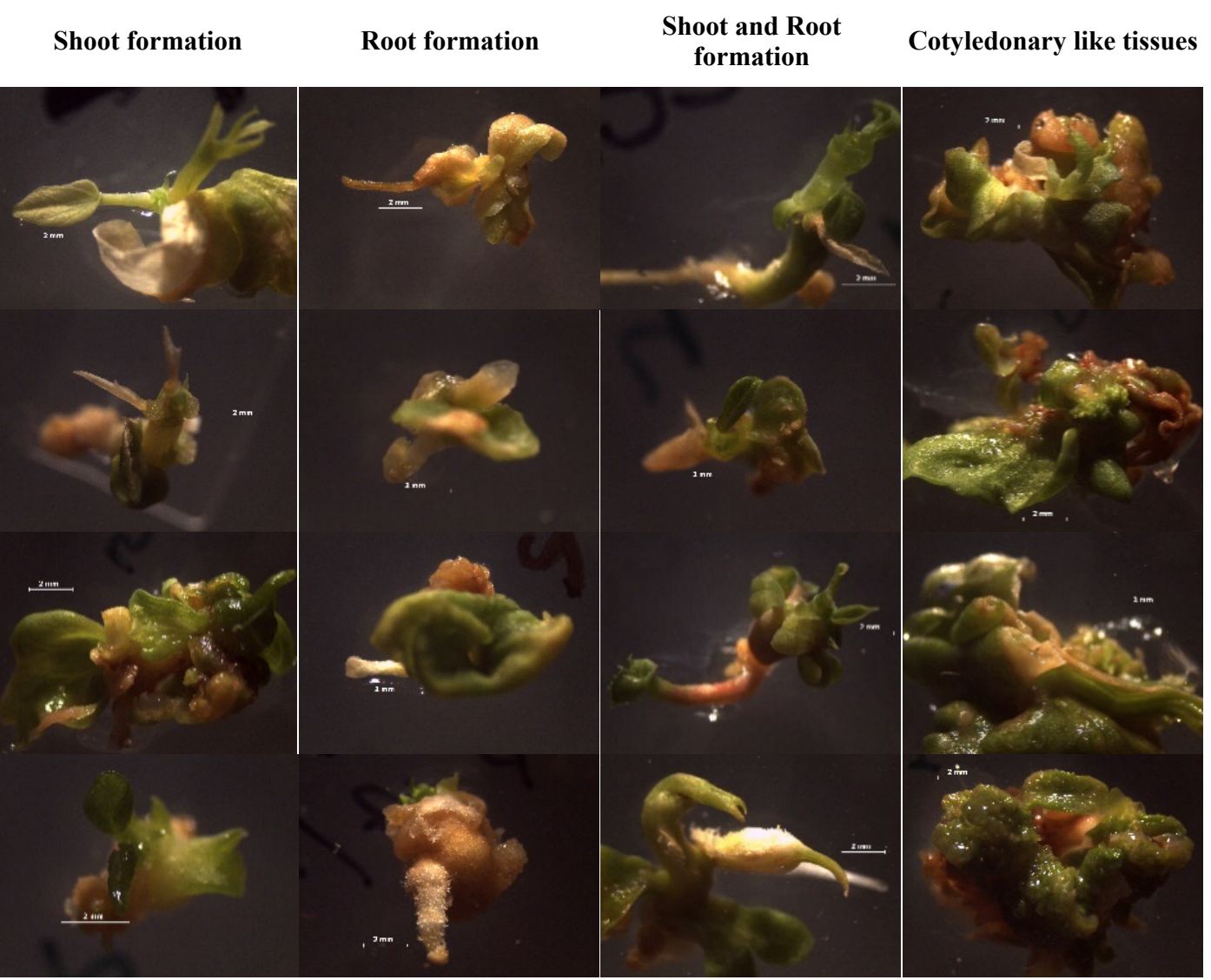

Figure 4. The morphological performances of cotyledonary like tissues derived from PSEs of ubi kuning after culturing in treatment media for three weeks. The left row showed the treatment media consisted with various concentration of BAP, while the above column showed the growth parameters including shoot, root, shoot and root formation and the cotyledonary like tissues formation. 


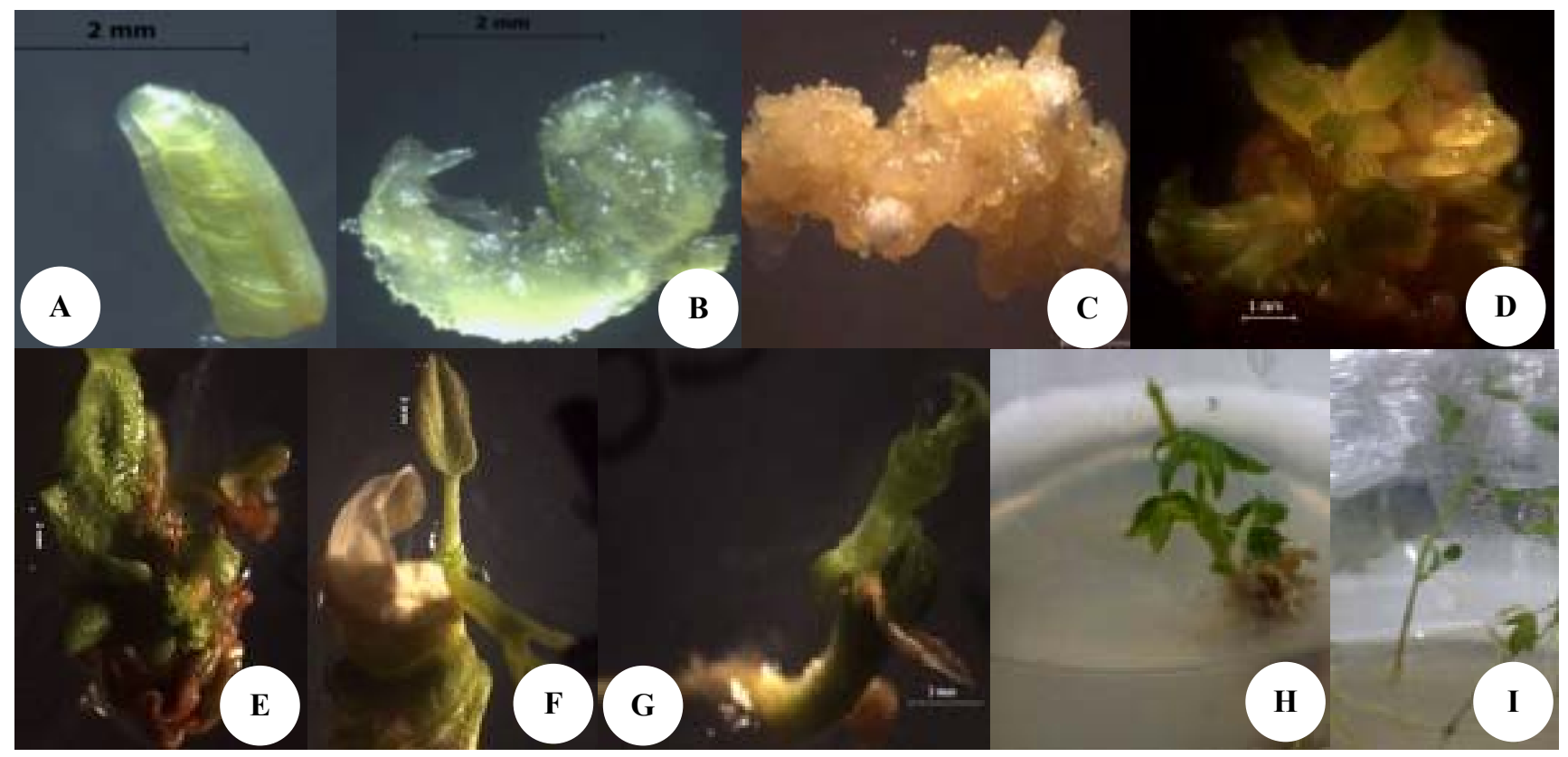

Figure 5. Cyclic somatic embryogenesis and regeneration of ubi kuning derived from leaf lobes explants. A. Leaf lobe explant with size of 1-3 mm; B. Embryogenic callus; C. Preembrionic stages of somatic embryos; D Immature cotyledon stage of somatic embryos; E. Cotyledonary like-tissues; F. Shoot growth; G. Shoot and root growth; H. Plantlet with young full-leaves and root; I. Mature plantlets ready to be acclimatized in the field.

\section{ACKNOWLEDGEMENTS}

This research was part of the "DIPA Unggulan" Research Grant of Indonesian Institute of Sciences (LIPI) Project 2017. The authors would like to thanks to $\mathrm{Mr}$. Nawawi for providing explants from the fields and $\mathrm{Mr}$. Tomey Indrianto for regenerating explants to be plantlets.

\section{REFERENCES}

Aboshama HMS. 2011. Somatic embryogenesis proliferation, maturation and germination in Cajanus cajan. World J Agric Sci 7 (1): 86-95.

Atehnkeng J, Adetimirin VO, Ng SYC. 2006. Exploring the African cassava (Manihot esculenta Crantz) germplasm for somatic embryogenic competence. African J Biotechnol 5 (14): 1324-1329.

D’Onofrio C \& Morini S. 2005. Development of adventitious shoots from in vitro grown Cydonia oblonga leaves as influenced by different cytokinins and treatment duration. Biologia Plantarum 49 (1): 17-21.

Fitriani H, Rahman N, Hartati NS, and Sudarmonowati E. 2012. Critical Factors in The Success of Induction and Maturation of Secondary Somatic Embryos of Local Indonesian Cassava Genotype "Roti" and "Apuy". Proceedings on National Seminar Indonesian Chemical Collaboration Network 19 Juni 2014 . [Indonesian]

Feitosa T, Bastos JLP, Ponte, LFA, Jucá TL, Campos, FDADP. 2007. Somatic embryogenesis in cassava genotypes from the northeast of Brazil. Braz Arch Biol Technol 50 (2): 201-206.

Ferreira CF, Alves E, Pestana KN, Junghans DT, Kobayashi AK, Santos VDJ, et al. 2008. Molecular characterization of Cassava with yelloworange roots for beta-carotene improvement. Crop Breed Appl Biotechnol 8 (1): 23-29.

Hankoua BB, Ng SYC, Fawole I, Puonti-Kaerlas J, Pillay M, Dixon AGO. 2005. Regeneration of a wide range of African cassava genotypes via shoot organogenesis from cotyledons of maturing somatic embryos and conformity of the field-established regenerants. Plant Cell Tiss Org Cult 82 (2): 221-231
Hartati NS, Fitriani H, Supatmi, Sudarmonowati E. 2012. The tuber root characterization and nutrition from seven cassava genotypes (Manihott esculenta). Agricola 2 (2): 101-110. [Indonesian]

Hartati NS, Supatmi, Aryaningrum PD, Sudarmonowati E. 2013. Identification of differentially expressed cDNA in cassava under drought stress using cDNA-RAPD approach. Annales Bogoriensis. 17 (1): 7-14.

Hermiati E, Mangunwidjaja, D, Sunarti TC, Suparno O, Prasetya B. 2012. Potential utilization of cassava pulp for ethanol production in Indonesia. Sci Res Essays 7 (2): 100-106.

Husaini AM, Mercado JA, da Silva JAT, Schaart JG. 2011. Review of factors affecting organogenesis, somatic embryogenesis and agrobacterium tumefaciens-mediated transformation of strawberry. Genes Genomes and Genomics 5 (Special Issue 1): 1-11.

Ihemere UE. 2003. Somatic Embryogenesis and Transformation of Cassava for Enhanced Starch Production [Dissertation]. Ohio State University, USA.

Jiménez VM. 2001. Regulation of in vitro somatic embryogenesis with emphasis on to the role of endogenous hormones. Revista Brasileira de Fisiologia Vegetal 13 (2): 196-223.

Karami O, Kordestani GK. 2007. Proliferation, shoot organogenesis and somatic embryogenesis in embryogenic callus of carnation. J Fruit Ornament Plant Res 15: 167.

Kamle1\&2 M, Bajpai A, Chandra R, Kalim S, Kumar R. 2011. Somatic embryogenesis for crop improvement. GERF Bull Biosci 2 (1): 54-59

Kumar JV, Kumari BR, Castano E. 2008. Cyclic somatic embryogenesis and efficient plant regeneration from callus of safflower. Biologia Plantarum 52 (3): 429-436.

Kurakawa T, Ueda N, Maekawa M, Kobayashi K, Kojima, M, NagatoY, et al.. 2007. Direct control of shoot meristem activity by a cytokininactivating enzyme. Nature 445 (7128): 652.

Kordestani GK, Karami, OMID. 2008. Picloram-induced somatic embryogenesis in leaves of strawberry (Fragaria ananassa L.). Acta Biologica Cracoviensia Series Botanica 50 (1): 69-72.

Malabadi RB, Van Staden J. 2005. Storability and germination of sodium alginate encapsulated somatic embryos derived from the vegetative shoot apices of mature Pinus patula trees. Plant Cell Tiss Org Cult 82 (3): 259-265 
Murashige T, Skoog F. 1962. A revised medium for rapid growth and bio assays with tobacco tissue cultures. Physiologia Plantarum 15 (3): 473-497.

Montagnac JA, Davis CR, Tanumihardjo SA. 2009. Nutritional value of cassava for use as a staple food and recent advances for improvement. Comp Rev Food Sci Food Saf 8 (3): 181-194.

Mohd M, Taqi AK, Firoz M. 2011. Cytokinins, A classical multifaceted hormone in plant system. J Stress Physiol Biochem 7 (4):347-368.

Mburu FW, Swaleh S, Njue W. 2012. Potential toxic levels of cyanide in cassava (Manihot esculenta Crantz) grown in Kenya. African J Food Sci 6 (16): 416-420.

Njoku DN, Vernon G, Egesi CN, Asante I, Offei SK, Okogbenin E, et al. 2011. Breeding for enhanced $\beta$-carotene content in cassava: constraints and accomplishments. J Crop Improv 25 (5): 560-571.

Onwubiku IOI. 2007. Micropropagation of Cassava (Manihot esculantum Crantz) Using Different Concentrations of Benzyaminiopurine (BAP). J Engin Appl Sci 2 (7): 1229-1231.

Ravindran BM, Winter S, Thangaraj M. 2015. Influence of Age of Explants and Genotype on Somatic Embryogenesis in African and Indian Cassava Cultivars. J Root Crops 40 (2): 21-27.

Saelim L, Phansiri S, Netrphan S, Suksangpanomrung M, Narangajavana J. 2006. Optimization of in vitro cyclic somatic embryogenesis and regeneration of the asian cultivars of cassava (Manihot esculento Crantz) for genetic manipulation system. Global $\mathrm{J}$ Biotechnol Biochem 1 (1): 07-15.

Sudarmonowati E. Fitriani H, Supatmi, Ardiyanti N. 2009. Factors affecting friable embryogenic callus in several plant species. Journal of Biotechnology Research in Tropical Region 2 No. 2, Oct.. 2009.

Ssemakula G, Dixon AGO, Dixon BM. 2008. Stability of total carotenoid concentration and fresh yield of selected yellow-fleshed cassava (Manihot esculenta Crantz). J Trop Agric 45 (1): 14-20.

Stasolla C, Yeung EC. 2003. Recent advances in conifer somatic embryogenesis: improving somatic embryo quality. Plant Cell Tiss Org Cult 74 (1): 15-35.

Thakkar SK, Huo T, Maziya-Dixon B, Failla ML. 2009. Impact of style of processing on retention and bioaccessibility of $\beta$-carotene in cassava (Manihot esculanta, Crantz). J Agric Food Chem 57 (4): 1344-1348.

Von Arnold S, Sabala I, Bozhkov P, Dyachok J, Filonova L. 2002. Developmental pathways of somatic embryogenesis. Plant Cell Tiss Org Cult 69 (3): 233-249.

Zavattieri MA, Frederica, AM, Lima, M, Sabino R, Arnholdt-Schmitt B. 2010. Induction of somatic embryogenesis as an example of stressrelated plant reactions. Elec J Biotechnol 13 (1): 12-13. 